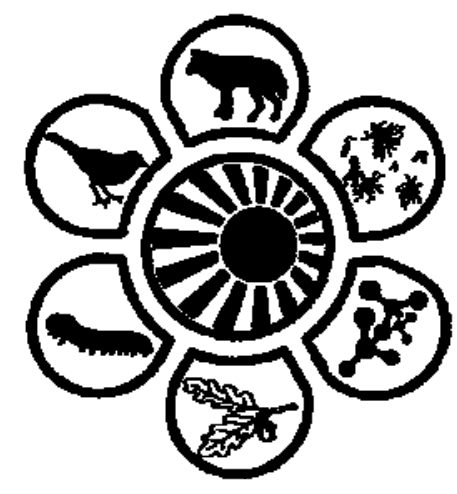

Вісник Дніпропетровського університету. Біологія, екологія.

Vìsnik Dnìpropetrovs'kogo unìversitetu. Serîa Bìologîâ, ekologiâ

Visnyk of Dnipropetrovsk University. Biology, ecology.

Vìsn. Dnìpropetr. Unìv. Ser. Bìol. Ekol. 2016. 24(2), 430-436.

doi: $10.15421 / 011658$

ISSN 2310-0842 print

ISSN 2312-301X online

www.ecology.dp.ua

УДК 636.034+636.084

Продуктивность лактирующих коров

при использовании в рационах сенажа из вико-овсяно-гороховой смеси с внесением нового биологического консерванта

\author{
П.И. Барышников ${ }^{1}$, В.Н. Хаустов ${ }^{1}$, С.В. Бурцева ${ }^{1}$, Р.В. Некрасов ${ }^{1}$, \\ М.Г. Чабаев ${ }^{1}$, А.А. Зеленченкова ${ }^{1}$, Д.А. Дурникин ${ }^{2}$ \\ ${ }^{1}$ Алтайский государственный аграрный университет, Барнаул, Россия \\ ${ }^{2}$ Алтайский государственный университет, Барнаул, Россия
}

Исследовано влияние нового биологического консерванта, представляющего собой смесь лиофильно высушенных бактерий: Lactobacillus plantarum ВКПМ В-4173, Lactococcus lactis subsp. lactis ВКПМ В-2092 и Propionibacterium acidipropionici ВКПМ B-5723 (в соотношении $40: 40: 20$ ) на качество сенажа из вико-овсяно-гороховой смеси. Общее содержание бактерий в консерванте составляло $1 \cdot 10^{11} \mathrm{KOE} / г$. В лабораторном опыте оценены четыре варианта закладки сенажа из люцерны, приготовленного в фазе бутонизации, с нормами внесения консерванта 3 и 6 г/т в присутствии и в отсутствие ферментов. В качестве контроля использовали самоконсервированный сенаж. По результатам эксперимента наилучшие результаты обеспечивало внесение биоконсерванта в количестве 6 г/т как совместно с ферментом, так и без него. В этих вариантах отмечена высокая сохранность протеина (94,5\% и 94,3\% от содержания в исходной массе) и высокое содержание молочной кислоты $(65,4 \%$ и $62,9 \%$ от общего содержания всех кислот), а также хорошие органолептические показатели. Указанная оптимальная норма внесения биоконсерванта протестирована в производственных испытаниях при закладке 750 тонн сенажа из вико-овсяно-гороховой смеси. Применение биоконсерванта позволило получить сенаж высокого качества, имеющий высокую энергетическую и питательную ценность. Проведены производственные испытания с оценкой эффекта скармливания сенажа, заготовленного путем самоконсервирования (контроль) и с внесением исследуемого биоконсерванта (опыт), на молочную продуктивность новотельных коров черно-пестрой породы (n = 15), качество молока и затраты кормов на единицу продукции. Среднесуточный удой молока базисной жирности $(3,4 \%)$ коров опытной группы в период раздоя составил 32,7 кг, что на $7 \%$ выше по сравнению с контрольными животными, получавшими самоконсервированный сенаж. Скармливание молочным коровам в период раздоя сенажа из вико-овсяно-гороховой смеси с внесением нового биологического консерванта обеспечило экономию в размере 4862 рубля на голову в ценах 2015-2016 года.

Ключевые слова: Lactobacillus plantarum; Lactococcus lactis; Propionibacterium acidipropionici; молочная продуктивность

\title{
Productivity of lactating cows fed on a diet of haylage from a vetch pea-oat mixture with the introduction of new biological preservative
}

\author{
P.I. Baryshnikov ${ }^{1}$, V.N. Khaustov ${ }^{1}$, S.V. Burtseva ${ }^{1}$, R.V. Nekrasov ${ }^{1}$, \\ M.G. Chabaev ${ }^{1}$, A.A. Zelenchikova ${ }^{1}$, D.A. Durnikin ${ }^{2}$ \\ ${ }^{I}$ Altai State Agrarian University, Barnaul, Russia \\ ${ }^{2}$ Altai State University, Barnaul, Russia
}

The effect of a new biological preservative representing a mix of lyophilized Lactobacillus plantarum VKPM V-4173, Lactococcus lactis subsp. lactis VKPM V-2092 and Propionibacterium acidipropionici VKPMV-5723 strains (40:40:20) on the quality of haylage pre-

Алтайский государственныій аграрный университет, ул. Попова, 276, Барнаул, 656922, Россия

Altai State Agrarian University, Popov Str., 276, Barnaul, 656922, Russia

E-mail:engbio@rambler.ru,haustovvn@mail.ru,sve-burceva@yandex.ru,nek_roman@mail.ru,chabaev.m.g-1@mail.ru,aly4383@mail.ru

Алтайский государственньй университет, пр. Ленина, 61, Барнаул, 656049, Россия

Altai State University, Lenin Ave., 61, Barnaul, 656049, Russia

E-mail:durnikin@list.ru 
pared from a mix of vetch, oats, and pea has been studied. The total bacteria content in the preservative was $1 \cdot 10^{11} \mathrm{CFU} / \mathrm{g}$. Five different variants of conservation of alfalfa haylage prepared at the budding stage were evaluated under laboratory conditions. The variants included a self-conserved control and the preservative at two different dosages ( 3 and $6 \mathrm{~g} /$ ton) with and without the addition of cellulolytic enzymes. The best results were observed in the case of both the enzyme-free and the enzyme-containing preservative at the dosage equal to $6 \mathrm{~g} /$ ton. These variants provided the maximum protein content in the haylage ( $94.3 \%$ and $94.5 \%$ of the initial content, respectively) and a high content of lactic acid $(62.9 \%$ and $65.4 \%$ of the total acid content, respectively) and also good organoleptic characteristics. The determined optimum biopreservative dosage was tested under industrial conditions using 750 tons of vetch-oats-pea haylage. The use of the biopreservative provided a high-quality haylage of high nutritive value. Industrial evaluation of the effect on the productivity of milk cattle $(n=15)$ of the addition of the biopreservative to the haylage showed that the maximum average daily yield of milk with basic fat content (3.4\%) was obtained from cows of the experimental group whose ration included haylage prepared with the use of the studied preservative. This yield came to $32.7 \mathrm{~kg}$, which exceeded the yield for the control group (fed on self-conserved haylage) by $7.0 \%$. Three months feeding of cows with the haylage prepared with the use of the new preservative brought a significant saving of money (4,862 rubles per a head at the prices of 2015-2016).

Keywords: Lactobacillus plantarum; Lactococcus lactis; Propionibacterium acidipropionici; milk productivity

\section{Введение}

Увеличение производства кормов и правильное их использование является одной из важнейших проблем современного сельскохозяйственного производства. Сложность и важность этой проблемы определяются тем, что укрепление кормовой базы в ближайшие годы должно осуществляться не за счет расширения посевных площадей под кормовые культуры, а преимущественно за счет повышения их урожайности и питательной ценности, а также снижения потерь при уборке, хранении и подготовке к скармливанию (Ross et al., 2004; Eliseev et al., 2011). Существующие технологии обеспечивают возможность заготовки кормов высокого качества. Одним из элементов технологии заготовки высококачественного сенажа, влияющих на его энергетическую и питательную ценность, является использование биологических консервантов, способствующее снижению биохимических потерь в 1,5-2,0 раза и, как следствие, обеспечивающее сохранность питательных веществ и каротина на уровне до 90-95\% от их исходного содержания (Zubrilin and Mishustin, 1958; Bondarev, 1975; Lithourgidis et al., 2006; Staniak et al., 2014).

В состав биологических консервантов входят живые культуры молочнокислых бактерий одного или нескольких видов, которые продуцируют молочную кислоту, подавляющую развитие нежелательной анаэробной микрофлоры. С целью предупреждения развития аэробной микрофлоры производители заквасок используют гетероферментативные молочнокислые бактерии, прежде всего Lactobacillus buchneri, а также пропионовокислые бактерии. Как первые, так и вторые способны синтезировать и накапливать в массе корма пропионовую кислоту и некоторые другие продукты, угнетающие развитие дрожжей и плесени. Кроме того, ряд заквасок содержит ферменты, способные расщеплять клетчатку растительных клеток до простых сахаров. В результате можно успешно заквашивать трудносилосуемые корма или работать в сложных погодных условиях, что обеспечивает определенное преимущество биологических консервантов по сравнению с химическими консервантами.

Другие причины популярности биологических консервантов - меньшая стоимость, большая технологичность, экологичность: они не токсичны, не вызывают раздражения кожи, слизистых оболочек, не имеют запаxa (Mikhin, 1937; Makarova, 1952; Danilenko et al., 1972; Zafren, 1977; Shcheglov et al., 1990; Vladimirov et al., 2001; Duborezov et al., 2005; Tuna and Orak, 2007; Doré et al., 2011). Научные исследования последних лет направлены на поиск еще более эффективных, дешевых, удобных в применении экологически чистых биологических консервантов.

Цель данной работы - оценить эффективность использования нового отечественного биологического консерванта при заготовке и хранении сенажа, степень сохранности в нем питательных веществ, а также оценить изменения молочной продуктивности лактирующих коров при скармливании им сенажа с добавкой биоконсерванта. Для решения поставленной цели изучены такие вопросы:

- влияние добавки различных концентраций биоконсерванта на динамику накопления аммиака, органических кислот, активную кислотность $(\mathrm{pH})$, сохранность и величину потерь питательных веществ при хранении сенажа, заложенного в лабораторных и производственных условиях;

- эффективность включения сенажа из подвяленной вико-овсяно-гороховой смеси, приготовленного с внесением исследуемого биоконсерванта, в рацион лактирующих коров, его влияние на выход и качество продукции, и перевариваемость питательных веществ;

- сравнение эффекта от скармливания сенажа с внесением биоконсерванта и без него в отношении состояния здоровья, биохимического состава крови и показателей рубцового содержимого подопытных животных;

Кроме того, на основе полученных данных выполнена оценка экономической эффективности применения нового биоконсерванта для заготовки сенажа, включаемого в рацион новотельных коров при раздое.

\section{Материал и методы исследований}

Исследования влияния консерванта при заготовке сенажа выполнены с привлечением специалистов ВИЖ им. Л.К. Эрнста и ФГБНУ РосНИИСК «Россорго». Производственные испытания биоконсерванта при заготовке сенажа из вико-овсяно-гороховой смеси проведены на базе ООО «Лестехстрой», г. Москва.

Объектом исследований являлся новый биологический консервант для силосования сельскохозяйственных культур, представляющий собой сухой порошок из лиофильно высушенных бактерий Lactobacillus plantarum (ВКПМ В-4173), Lactococcus lactis subsp. lactis (ВКПМ В-2092), Propionibacterium acidipropionici (ВКПМ В-5723) в соотношении $40: 40: 20$, соответственно, а также вариант вышеописанного биоконсерванта, допол- 
нительно содержащий фермент Целлолюкс-F в количестве 50 г/кг препарата. Общее содержание молочнокислых и пропионовокислых бактерий в порошке биоконсерванта составляло $1 \cdot 10^{11} \mathrm{KOE} / г$. В качестве вспомогательного вещества для нормализации титра использовали сухую молочную сыворотку. Препарат стабилен в сухом виде. Стоимость исследуемого биоконсерванта на 2014-2015 г. составляла 2500 р./кг.

На первом этапе исследования в лаборатории кормопроизводства РосНИИСК «Россорго» был оценен эффект различных норм внесения биоконсерванта на качество сенажа из трудносилосуемой культуры - люцерны в фазе бутонизации. Подвяленную массу люцерны закладывали на сенаж в стеклянные сосуды объемом 3 л в четырех опытных и одном контрольном вариантах. Количество добавляемого биоконсерванта в опытных вариантах составило 3 и 6 г на тонну закладываемой массы. Еще два опытных варианта включали аналогичные дозировки биоконсерванта, дополнительно содержащего ферментный препарат Целлолюкс-F. В контрольном варианте биоконсервант в зеленую массу не добавляли.

В готовом сенаже определяли содержание аммиака и уровень рН (ГОСТ 26180-84 «Методы определения аммиачного азота и активной кислотности (pH)»), количество молочной, уксусной и масляной кислот и их соотношение (ГОСТ 23638-90 «Силос из зеленых растений»), а также химический состав проб кормов по методикам, принятым в отделе кормопроизводства и технологии приготовления кормов ФГБНУ РосНИИСК «Россорго».

Производственная закладка сенажа из подвяленной массы вико-овсяно-гороховой смеси с внесением биологического консерванта в количестве 6 г/т осуществлена на площадях ООО «Лестехстрой». Объем сенажа, заложенного с биоконсервантом, составил 750 тонн. Объем сенажа, заложенного без консерванта, составил 2250 тонн. Химический состав и качество заложенных производственных сенажей определяли в химико-аналитической лаборатории ВИЖ им. Л.К. Эрнста по стандартным методикам (Raetskaya et al., 1979).

Далее в рамках производственных испытаний на базе ООО «Лестехстрой» на лактирующих коровах черно- пестрой породы в период раздоя проведен научнохозяйственный опыт по сравнению эффективности скармливания сенажа, приготовленного с применением нового консерванта и без него. В первой (контрольной) группе животных рацион кормления включал самоконсервированный сенаж. Во второй (опытной) группе коров включенный в рацион сенаж готовили с внесением исследуемого биоконсерванта (6 г/т). Количество коров в каждой группе - 15 голов.

Продолжительность учетного периода опыта составила 120 дней. Контроль над молочной продуктивностью коров осуществляли ежемесячно. Пробы молока отбирали в соответствии с ГОСТ 13928-84. Молоко исследовали в лаборатории селекционного контроля качества молока и молочных продуктов ВИЖ им Л.К. Эрнста на анализаторе Bentley 150 (ГОСТ 5867-90, ГОСТ 25179-90, ГОСТ 3626-73, ГОСТ 3625-84, ГОСТ 3624-92). При выполнении исследований химического состава молока жирность определяли кислотным методом Гербера, а белок - методом формольного титрования.

Исходя из данных по затратам на приготовление кормов, их стоимости и полученной молочной продуктивности, рассчитан относительный экономический эффект от использования нового биологического консерванта при закладке сенажа.

Статистическая обработка полученных в опытах данных проведена с использованием однофакторного дисперсионного анализа для повторных измерений.

\section{Результаты и их обсуждение}

Спустя три месяца после закладки сенажа в лабораторном опыте наилучшие показатели по содержанию органических кислот отмечены при добавлении биоконсерванта в количестве 6 г/т в комплексе с ферментом Целлолюкс-F и без него (2,89\% и 2,94\%). При этом доля молочной кислоты составила соответственно 1,89\% и $1,85 \%$, уксусной $-1,00 \%$ и $1,09 \%$. Соотношение молочной и уксусной кислот в этих вариантах составило 62,9 : 37,1 и $65,4: 34,6$, соответственно (табл. 1).

Количество кислот и их соотношение в сенаже (90-й день закладки; $\mathrm{M} \pm \mathbf{m}, \mathbf{n}=3$ )

Таблица 1

\begin{tabular}{|l|c|c|c|c|c|c|c|}
\hline \multirow{2}{*}{\multicolumn{1}{c|}{ Вариант сенажа }} & \multicolumn{3}{c|}{ Количество кислот, \% } & \multicolumn{3}{c|}{ Сумма } & \multicolumn{3}{c|}{ Соотношение кислот, \% } \\
\cline { 2 - 3 } \cline { 6 - 8 } & молочная & уксусная & масляная & кислот, \% & молочная & уксусная & масляная \\
\hline Контроль (самоконсервирование) & $1,45 \pm 0,09$ & $0,97 \pm 0,05$ & $0,20 \pm 0,03$ & $2,62 \pm 0,09$ & 55,40 & 37,0 & 7,60 \\
\hline Биоконсервант, 3 г/т & $1,56 \pm 0,07$ & $0,99 \pm 0,10$ & $0,03 \pm 0,02$ & $2,58 \pm 0,15$ & 60,40 & 38,40 & 1,20 \\
\hline Биоконсервант, 6 г/т & $1,85 \pm 0,05$ & $1,09 \pm 0,13$ & - & $2,94 \pm 0,10$ & 62,90 & 37,10 & - \\
\hline Биоконсервант, 3 г/т + фермент* & $1,63 \pm 0,07$ & $0,96 \pm 0,10$ & $0,03 \pm 0,02$ & $2,62 \pm 0,10$ & 62,20 & 36,60 & 1,10 \\
\hline Биоконсервант, 6 г/т + фермент & $1,89 \pm 0,28$ & $1,00 \pm 0,16$ & - & $2,89 \pm 0,13$ & 65,40 & 34,60 & - \\
\hline
\end{tabular}

Примечание: * - вариант биоконсерванта с добавлением ферментативного препарата Целлолюкс-F в дозировке 50 г/кг препарата.

В контрольном сенаже содержание органических кислот составило $2,62 \%$, что на $0,32 \%$ и $0,27 \%$ ниже по сравнению с результатами, полученными при внесении 6 г/т биоконсерванта без или вместе с ферментом, соответственно. Доля молочной кислоты в контроле составила $55,4 \%$, уксусной $-37,0 \%$, масляной $-7,6 \%$.

Степень распада белковых веществ оценивали по содержанию аммиака в сенаже в конце периода хранения. Гидролиз протеина в самоконсервированном люцерновом сенаже проходил активнее: за три месяца хранения содержание аммиака составило 671 ppm (табл. 2). Гидролиз белка в сенаже с внесением биоконсерванта в количестве 3 г/т и этой же дозировки с включением фермента протекал несколько медленнее и составил за этот же срок хранения только 40,5 и 38,9 мг\%, соответственно, что на 266 и 282 ррт меньше, чем в самоконсервированном сенаже.

Содержание аммиака в сенаже с добавкой биоконсерванта в количестве 6 г/т или этой же дозировки в 
комбинации с ферментом составило 354 и 341 ppm соответственно, что на 317 и 330 ppm меньше по сравнению с контролем и на 51 и 48 ppm меньше, чем для меньшей дозировки биоконсерванта. Похожие данные по содержанию аммиака при самоконсервировании сенажа из люцерны были получены в опытах Шмидта и Веттерау (1975); при этом авторы указывают, что аммиак снижает кислотность силоса и усиливает развитие гнилостных бактерий, ухудшая качество силоса.

Оценка уровня активной кислотности показала, что наилучшие результаты достигнуты при внесении биоконсерванта в дозировке 6 г/т; в этом случае $\mathrm{pH}$ сенажа к концу периода хранения составила 4,6 (биоконсервант) и 4,5 (биоконсервант + фермент), в то время как в контроле $\mathrm{pH}$ составил 5,6.

Оценка сохранности питательных веществ в сенаже показала, что внесение 6 г/т биоконсерванта без фермента и вместе с ним позволило увеличить сохранность протеина в абсолютно сухом веществе сенажа на 5,69\% и 5,93\%, а жиров - на 5,78\% и $1,19 \%$, соответственно, по сравнению с самоконсервированным сенажом. В то же время, существенных различий в количестве золы, сырой клетчатки и безазотистых экстрактивных веществ между исследованными вариантами сенажа не обнаружено (табл. 3).

Таблий 2

Динамика изменения содержания аммиака и уровня рН в исследуемых образцах $(\mathrm{M} \pm \mathbf{m}, \mathbf{n}=3)$

\begin{tabular}{|c|c|c|c|c|c|c|}
\hline \multirow{3}{*}{ Вариант закладки } & \multicolumn{6}{|c|}{ Показатель } \\
\hline & \multicolumn{3}{|c|}{ Содержание аммиака, ppm } & \multicolumn{3}{|c|}{$\mathrm{pH}$} \\
\hline & 7 & 21 & 60 & 7 & 21 & 60 \\
\hline Самоконсервирование & $644,7 \pm 1,28$ & $655,7 \pm 0,85$ & $670,7 \pm 0,79$ & $5,67 \pm 0,03$ & $5,67 \pm 0,03$ & $5,63 \pm 0,03$ \\
\hline $3 \Gamma / \mathrm{T}$ & $397,7 \pm 1,03$ & $392,3 \pm 1,66$ & $405,0 \pm 1,58$ & $5,07 \pm 0,03$ & $5,20 \pm 0,00$ & $5,17 \pm 0,03$ \\
\hline $6 \Gamma / \mathrm{T}$ & $360,7 \pm 0,35$ & $357,3 \pm 0,98$ & $354,3 \pm 0,77$ & $4,67 \pm 0,03$ & $4,60 \pm 0,00$ & $4,60 \pm 0,00$ \\
\hline 3 г/T + фермент* & $400,7 \pm 2,27$ & $387,3 \pm 1,31$ & $389,0 \pm 1,17$ & $5,07 \pm 0,03$ & $4,97 \pm 0,03$ & $4,90 \pm 0,00$ \\
\hline 6 г/T + фермент & $346,3 \pm 2,32$ & $338,3 \pm 1,26$ & $340,7 \pm 0,79$ & $4,67 \pm 0,03$ & $4,37 \pm 0,03$ & $4,47 \pm 0,03$ \\
\hline
\end{tabular}

Примечание: * - см. табл. 1.

Таблииа 3

Сохранность питательных веществ в сенаже (90-й день закладки)

\begin{tabular}{|c|c|c|c|c|c|c|}
\hline \multirow{3}{*}{ Показатель } & \multirow{3}{*}{$\begin{array}{c}\text { Содержание } \\
\text { в исходной } \\
\text { массе, } \%\end{array}$} & \multicolumn{5}{|c|}{ Сохранность питательных веществ в абсолютно сухом веществе, \% } \\
\hline & & \multirow{2}{*}{ контроль } & \multicolumn{2}{|c|}{ консервант } & \multicolumn{2}{|c|}{ консервант + фермент* } \\
\hline & & & $3 \Gamma / \mathrm{T}$ & $6 \Gamma / \mathrm{T}$ & $3 \Gamma / \mathrm{T}$ & $6 \Gamma / \mathrm{T}$ \\
\hline Сырой белок & 12,30 & 10,90 & 11,42 & 11,63 & 11,36 & 11,60 \\
\hline то же от исходной массы & - & 88,62 & 92,85 & 94,55 & 92,36 & 94,31 \\
\hline Сырой жир & 2,77 & 3,30 & 3,20 & 3,46 & 3,23 & 3,61 \\
\hline то же от исходной массы & - & 119,13 & 115,52 & 124,91 & 116,61 & 130,32 \\
\hline Сырая клетчатка & 30,20 & 31,30 & 31,46 & 32,2 & 31,35 & 31,65 \\
\hline то же от исходной массы & - & 103,64 & 104,17 & 106,62 & 103,81 & 104,80 \\
\hline Зола & 8,60 & 9,40 & 9,50 & 9,20 & 9,35 & 9,20 \\
\hline то же от исходной массы & - & 109,30 & 110,47 & 106,98 & 108,72 & 106,98 \\
\hline БЭВ** & 46,13 & 45,10 & 44,42 & 43,41 & 44,71 & 43,94 \\
\hline то же от исходной массы & - & 97,77 & 96,29 & 94,10 & 96,92 & 95,25 \\
\hline $\mathrm{ACB}^{* * *}$ & 31,81 & 31,95 & 32,10 & 31,93 & 31,90 & 32,08 \\
\hline
\end{tabular}

Примечания: * - см. табл. 1 ;* - безазотистые экстрактивные вещества; *** - абсолютно сухое вещество.

Полученные данные по сохранности питательных веществ согласуются с выводами М.М. Макаровой (Маkarova, 1962), И.А. Даниленко и др. (Danilenko et al., 1972) и С.Я. Зафрена (Zafren, 1977) о том, что внесение заквасок при силосовании трудносилосующихся кормов с пониженной влажностью ускоряет заквашивание корма и минимизирует потери питательных веществ.

По результатам органолептической оценки сенаж из люцерны в фазе бутонизации, приготовленный с внесением 6 г/т биоконсерванта как в присутствии, так и в отсутствие фермента обладал приятным запахом квашеных яблок и лучше сохранял первоначальный цвет и структуру по сравнению с другими вариантами. Таким образом, проведенный лабораторный опыт позволил определить оптимальную норму внесения биоконсерванта в подвяленную массу трудносилосуемой культуры люцерны в фазе бутонизации - 6 г/т.

В ходе производственного опыта с использованием сенажа из вико-овсяно-гороховой смеси показано, что новый биоконсервант оказал положительное влияние на сохранность энергии и питательных веществ в сенаже. По сравнению с контролем отмечено увеличение содержания в сенаже сухого вещества на 2,47\%, сырого протеина - на 3,0\% и обменной энергии - на 9,0\% (табл. 4).

Максимальные изменения отмечены для углеводов, являющихся хорошим субстратом для молочнокислых и других бактерий. В процессе хранения сенажа из викоовсяно-гороховой смеси с внесением нового биологического консерванта содержание клетчатки уменьшилось на 14\% по сравнению с контролем, что, возможно, связано с меньшими потерями азотистых веществ и углеводов. В отношении содержания каротина и фосфора существенных различий между опытным и контрольным вариантами выявлено не было. Таким образом, внесение в сенаж нового биоконсерванта обеспечило сохранение высокого его качества по органолептическим свойствам и значительное увеличение содержания сухого вещества, белков, жиров и минеральных веществ.

Научно-хозяйственный опыт, проведенный на коровах в период их раздоя в условиях ООО «Лестехстрой» 
(г. Москва), не выявил различий по степени удовлетворения потребности животных в необходимом количестве энергии, питательных и биологически активных веществ. Анализ молочной продуктивности показал, что среднесуточные удои натурального молока у коров опытной группы, получавших сенаж с добавкой нового биоконсерванта в количестве 6 г/т, оказались на 9,3\% выше, чем у животных контрольной группы (табл. 5). Среднесуточный удой молока жирностью 3,4\% также оказался максимальным в опытной группе коров (32,7 кг, что на 7,0\% выше, чем в контрольной группе). Различия между коровами кон- трольной и опытной групп по валовому удою натурального и $3,4 \%$ молока составили 298,8 и 240,0 кг, соответственно. Содержание жира и белка в молоке коров обеих групп практически не различалось.

Выявленные в ходе эксперимента различия по продуктивным качествам животных представлены на рисунке. Более высокий уровень молочной продуктивности и жирности молока у животных опытной группы обусловлен, по-видимому, лучшим качеством сенажа, подготовленного с использованием нового биологического консерванта, и лучшей сбалансированностью рациона.

Таблица 4

Влияние исследуемого биоконсерванта на питательность и качество сенажа из вико-овсяно-гороховой смеси

\begin{tabular}{|l|c|c|}
\hline \multicolumn{1}{|c|}{ Показатель } & \multicolumn{2}{c|}{ Сенаж } \\
\cline { 2 - 3 } & без консерванта & 22,80 \\
\hline Сухое вещество, \% & 20,33 & 132,70 \\
\hline Сырой белок в сухом веществе, г/кг & 128,90 & 128,90 \\
\hline Сырой жир в сухом веществе, г/кг & 42,10 & 284,20 \\
\hline Сырая клетчатка в сухом веществе, г/кг & 323,10 & 16,30 \\
\hline Сырая зола в сухом веществе, г/кг & 19,70 & 71,50 \\
\hline Кальций в сухом веществе, $\Gamma /$ кг & 96,90 & 14,50 \\
\hline Фосфор в сухом веществе, $\Gamma /$ кг & 12,30 & 80,30 \\
\hline Каротин в сухом веществе, мг/кг & 86,60 & 9,13 \\
\hline Обменная энергия в сухом веществе, МДж/кг & 8,37 & 0,91 \\
\hline Энергетических кормовых единиц в сухом веществе & 0,84 & \\
\hline
\end{tabular}

Влияние добавления в сенаж нового биоконсерванта на молочную продуктивность и качество молока лактирующих коров $(\mathbf{M} \pm \mathbf{m}, \mathbf{n}=15)$

\begin{tabular}{|c|c|c|}
\hline \multirow{2}{*}{ Показатель } & \multicolumn{2}{|c|}{ Группа коров } \\
\hline & контрольная & опытная \\
\hline Среднесуточный удой молока натуральной жирности, кг & $26,87 \pm 0,90$ & $29,36 \pm 0,80^{*}$ \\
\hline то же, \% к контролю & 100,0 & 109,3 \\
\hline Массовая доля жира, \% & $3,88 \pm 0,07$ & $3,79 \pm 0,06$ \\
\hline Массовая доля белка, \% & $3,43 \pm 0,05$ & $3,44 \pm 0,08$ \\
\hline Среднесуточный удой молока 3,4\% жирности, кг & $30,7 \pm 1,2$ & $32,8 \pm 1,3^{*}$ \\
\hline то же, \% к контролю & 100,0 & 107,0 \\
\hline Валовой удой молока натуральной жирности, кг & $3224 \pm 96$ & $3523 \pm 101$ \\
\hline Валовой удой молока $3,4 \%$ жирности, кг & $3684 \pm 138$ & $3924 \pm 150$ \\
\hline Продукция молочного жира, кг & $125,1 \pm 4,7$ & $133,5 \pm 5,1$ \\
\hline \multicolumn{3}{|c|}{ Затрачено на 1 кт молока 3,4\% жирности } \\
\hline Обменная энергия, МДж & 7,10 & 6,90 \\
\hline Перевариваемого протеина, г & 62,6 & 60,9 \\
\hline
\end{tabular}

Примечание: *-достоверно при $\mathrm{P}<0,01$.

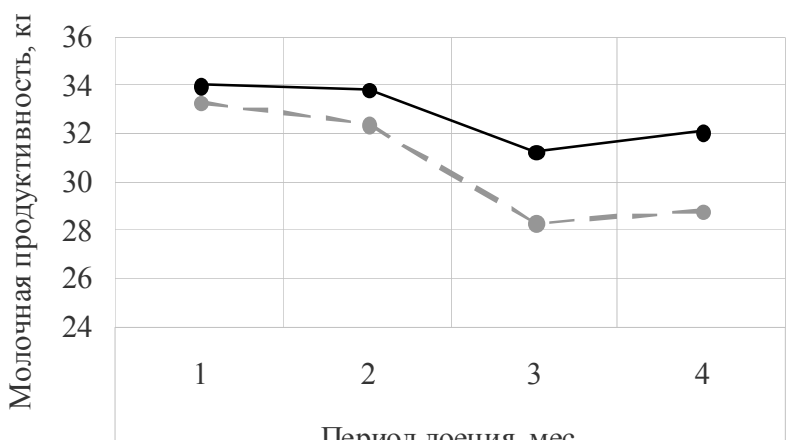

Период доения, мес.

- - 1-контрольная группа

-2-опытная группа

Рис. Лактационные кривые подопытных коров в период проведения научно-хозяйственного опыта (молоко базисной жирности)
Одним из основных показателей, характеризующих эффективность отрасли животноводства, является затрата кормов на единицу продукции. Анализ данных по затратам кормов на производство 1 кг молока жирностью 3,4\% показал, что включение в рационы лактирующих коров сенажа, подготовленного с использованием нового биологического консерванта в количестве 6 г/т, привело к снижению затрат обменной энергии и перевариваемого протеина на 2,9\% и 2,8\% соответственно по сравнению с животными контрольной группы.

На основании данных по расходу кормов и валового удоя молока подопытных животных за 120 дней лактации, а также материалов бухгалтерского учета рассчитана экономическая эффективность использования сенажа с внесением нового биологического консерванта в количестве 6 г/т в кормлении лактирующих коров (табл. 6). 
Таблииа 6

Экономическая эффективность добавления в сенаж нового биоконсерванта в пересчете на голову молочного скота

\begin{tabular}{|c|c|c|}
\hline \multirow{2}{*}{ Показатель } & \multicolumn{2}{|c|}{ Группа животных } \\
\hline & контрольная & опытная \\
\hline Стоимость кормов, руб. & 27098,4 & 27487,2 \\
\hline Стоимость консерванта, руб. & не применялся & 18,0 \\
\hline Стоимость кормов + стоимость консерванта, руб. & 27098,4 & 27487,3 \\
\hline Надоено молока 3,4\% жирности за 120 дней лактации, кг & 3680,0 & 3924,0 \\
\hline Реализационная цена 1 кг молока, руб. & 20,00 & 20,00 \\
\hline Дополнительный надой молока, кг & Нет & $+244,0$ \\
\hline Выручено от реализации молока, руб. & 73600,00 & 78480,00 \\
\hline Стоимость дополнительно полученного молока, руб. & не получен & $+4880,00$ \\
\hline $\begin{array}{l}\text { Превышение стоимости дополнительно полученного молока } \\
\text { над разницей в стоимости кормов, руб. }\end{array}$ & нет & $+4862,00$ \\
\hline
\end{tabular}

Расходы, направленные на приобретение консерванта, незначительно увеличили стоимость кормов для опытной группы, однако при этом надой молока жирностью 3,4\% оказался выше контроля на 244 кг, что обеспечило итоговую прибыль 4862 рубля. Таким образом, скармливание молочным коровам в течение 120 дней сенажа, приготовленного с использованием нового биологического консерванта, обеспечило прибыль в размере 4862 рубля на одну корову в ценах 2015-2016 годов.

\section{Выводы}

Внесение 6 г/т нового биологического консерванта при силосовании люцерны в фазе бутонизации способствует получению сенажа высокого качества в соответствии с органолептической и биохимической оценкой (цвет, запах, структура, активная кислотность, накопление аммиака, органических кислот брожения). Использование изучаемого консерванта в дозировке 6,0 г/т как в варианте с добавлением фермента, так и в его отсутствие, способствует снижению потерь протеина в 2,0-2,1 раза по сравнению с контролем (самоконсервирующимся сенажом).

Научно-хозяйственный опыт, проведенный на коровах в период их раздоя, показал, что включение в рационы лактирующих коров сенажа из вико-овсяно-гороховой смеси, подготовленного с добавлением нового биологического консерванта в дозировке 6 г/т, обеспечивает прирост удоя молока на 7,0\% и одновременное снижение потерь обменной энергии на $9 \%$, сухого вещества - на 2,5\%, сырого белка - на 3,0\% по сравнению с контролем. Скармливание молочным коровам сенажа с биоконсервантом в течение трех месяцев обеспечило прибыль в размере 4862 рубля на голову скота в ценах 2015-2016 гг.

На основании полученных результатов авторы считают целесообразным и обоснованным рекомендовать к использованию изученный биоконсервант для приготовления сенажа из вико-овсяно-гороховой смеси.

\section{Благодарности}

Работа выполнена при финансовой поддержке Министерства образования и науки РФ в рамках ФЦП «Исследование и разработки по приоритетным направлениям развития научно-технологического комплекса России на 2014-2020 годы» (соглашение о предоставлении субсидии № 14.607.21.0114 от 15.10.2015 г., RFMEF160715X0114).

\section{Библиографические ссылки}

Alemu, A.W., Doepel, L., 2011. Fenugreek (Trigonella foenumgraecum L.) as an alternative forage for dairy cows. Animal 5(9), 1370-1381.

Bondarev, V.A., 1975. Puti snizheniya poter' i povysheniya kachestva silosa [Ways to reduce losses of silage quality]. Kormoproizvodstvo 10, 18-24 (in Russian).

Celis-Alvarez, M.D., López-González, F., Martínez-García, C.G., Estrada-Flores, J.G., Arriaga-Jordán, C.M., 2016. Oat and ryegrass silage for small-scale dairy systems in the highlands of central Mexico. Trop. Anim. Health Prod. 48(6), $1129-1134$.

Danilenko, I.A., 1972. Silos [Silage]. Kolos, Moscow (in Russian).

Dordas, C.A., Vlachostergios, D.N., Lithourgidis, A.S., 2012. Growth dynamics and agronomic-economic benefits of peaoat and pea-barley intercrops. Crop Pasture Sci. 63,45-52.

Doré, T., Makowski, D., Malézieux, E., Munier-Jolain, N., Tchamitchian, M., Tittonell, P., 2011. Facing up to the paradigm of ecological intensification in agronomy: Revisiting methods, concepts and knowledge. Eur. J. Agron. 34(4), 197-210.

Duborezov, V.M., Vinogradov, V.N., Evstratov, A.I., Kirnos, I.O., Suslova, S.V., 2005. Progotovlenie ob'emistyh kormov s ispol'zovaniem konservantov razlichnoi prirody: Rekomendatsii [Preparation of roughage with different nature preservatives]. VIZh, Dubrovitsy (in Russian).

Eliseev, S.L., Renev, A., Reneva, I., 2014. Productivity of annual legume-grass mixtures according to interspecies competition. World Appl. Sci. J. 32(9), 1970-1973.

Fadul-Pacheco, L., Wattiaux, M.A., Espinoza-Ortega, A., Sánchez-Vera, E., Arriaga-Jordán, C.M., 2013. Evaluation of sustainability of smallholder dairy production systems in the highlands of Mexico during the rainy season. Agroecology and Sustainable Food Systems 37, 882-901.

Guadarrama-Estrada, J., Espinoza-Ortega, A., GonzálezEsquivel, C.E., Arriaga-Jordán, C.M., 2007. Inclusion of maize or oats-vetch silage for grazing dairy cows in smallscale campesino systems in the highlands of Central Mexico. J. Appl. Anim. Res. 32(1), 19-23.

Hernández-Ortega, M., Heredia-Nava, D., Espinoza-Ortega, A., Sánchez-Vera, E., Arriaga-Jordán, C.M., 2011. Effect of silage from ryegrass intercropped with winter or common vetch for grazing dairy cows in small-scale dairy systems in Mexico. Trop. Anim. Health Prod. 43, 947-954.

Kalashnikov, A.P., Fisinin, V.I., Shcheglov, V.V., Kleimenov, N.I. (eds.), 2003. Normy i ratsiony kormleniya selskokhozyaistvennyh zhivotnyh [Standards and ration feeding farm animals]. Rosselkhozakademiya, Moscow (in Russian).

Lithourgidis, A.S., Vsilakoglou, I.B., Dhima, K.V., Dordas, C.A., Yiakoulaki, M.D., 2006. Forage yield and quality of 
common vetch mixtures with oat and triticale in two seeding ratios. Field Crop Res. 99, 106-113.

Makarova, M.M., 1962. Mikrobiologiya silosa [Microbiology of silage]. Izdatel'stvo Selskokhozyaistvennoj Literatury i Plakatov, Moscow (in Russian).

Mikhin, A.M., 1937. Silosovanie kormov v zasushlivoi zone [Silage fodder in the arid zone]. Selkhozgiz, Moscow (in Russian).

Raetskaya, Y.I., Sukhareva, V.N., Samokhin, V.T., 1979. Metodika zootehnicheskih i biohimicheskih analizov kormov, produktov obmena i zhivotnovodcheskoi produktsii [Zootechnical technique and biochemical analyzes of feed, livestock production and exchange of products]. VIZh, Dubrovitsy (in Russian)

Ross, S.M., King, J.R., O’Donovan, J.T., Spaner, D., 2004. Forage potential of intercropping berseem clover with barley, oat, or triticale. Agron. J. 96, 1013-1020.

Shcheglov, V.V., Boyarskiy, L.G., 1990. Korma: Prigotovlenie, hranenie, ispolzovanie [Feed: Preparation, storage, use]. Agropromizdat, Moscow (in Russian).
Staniak, M., Jerzy Księżak, J., Bojarszczuk, J., 2014. Mixtures of legumes with cereals as a source of feed for animals. In: Pilipavicius, V. (ed.) Agricultural and biological sciences "Organic agriculture towards sustainability". In Tech.

Tuna, C., Orak, A., 2007. The role of intercropping on yield potential of Common vetch (Vicia sativa L.)/oat (Avena sativa L.) cultivated in pure stand and mixtures. J. Agric. Biol. Sci. 2(2), 14-19.

Vladimirov, V.L., Naumenko, P.A., Marinov, K.A., Fritberg, R.V., Bodrov, D.A., 2001. Tehnologiya prigotovleniya korma ponizhennoi vlazhnosti s primeneniem khimicheskikh konservantov [Technology of preparation of low humidity feed with chemical preservatives]. RUTs EBTZh, Dubrovitsy (in Russian).

Zafren, S.Y., 1977. Tehnologiya prigotovleniya kormov [Feed preparation technology]. Kolos, Moscow (in Russian).

Zubrilin, A.A., Mishustin, E.N., 1958. Silosovanie kormov [Silage fodder]. USSR Academy of Sciences, Moscow (in Russian).

Надійшла до редколегї 04.10.2016 